\title{
Acid and Metalliferous Drainage-A Global Environmental Issue
}

\author{
Gujie Qian'* and Yubiao Li $^{2}$ \\ ${ }^{1}$ College of Science and Engineering, Flinders University, Australia \\ ${ }^{2}$ School of Resources and Environmental Engineering, Wuhan University of Technology, China
}

*Corresponding author: Gujie Qian, College of Science and Engineering, Flinders University, Australia

\begin{abstract}
Acid and Metalliferous Drainage (AMD) is a critical environmental problem worldwide. It occurs when sulfide minerals, primarily pyrite, oxidise chemically or biologically to produce acidic wastewater containing elevated concentrations of sulfate and toxic elements. This short paper presents a very brief and general introduction of AMD, with a specific focus on two categories of AMD remediation options including source- and migration-control. Some most recent examples of potentially viable and economically sustainable surface passivation strategies for AMD control at-source are briefly discussed in this review.
\end{abstract}

\section{Introduction}

Acid and Metalliferous Drainage (AMD), acid mine drainage or acid rock drainage, is recognised as a critical global environmental issue, resulting predominantly from the oxidation of pyrite $\left(\mathrm{FeS}_{2}\right)$ $[1,2]$ "the most abundant sulfide mineral on the earth" [3] through chemical and microbially-mediated reactions with surface water and oxygen. The presence of some naturally occurring iron- and sulfur-oxidising bacteria (e.g. Acidithiobacillus ferrooxidans) can significantly accelerate pyrite oxidation, and therefore, microbial action plays an important role in the formation of AMD. AMD can occur due to natural weathering or anthropogenic activities such as mining. It is often associated with low $\mathrm{pH}(<\mathrm{pH} 4)$ and elevated concentrations of sulfate and toxic metal(loid)s such as $\mathrm{As}, \mathrm{Cd}, \mathrm{Pb}$, Se and $\mathrm{Zn} \mathrm{[4-6].} \mathrm{Acid} \mathrm{and} \mathrm{metal(loid)} \mathrm{runoff} \mathrm{can} \mathrm{impact} \mathrm{hundreds}$ of kilometres from the site along hydrologic gradients within relatively short times [7], and can devastate downstream rivers, streams and aquatic life. Treatment of runoff can be required for hundreds to thousands of years or "in perpetuity" [8]. The United Nations has recently acknowledged AMD as the second biggest global issue after global warming [9], highlighting the significance of this environmental challenge. AMD is widespread in resourcerich countries such as Australia, Brazil, Canada, Chile, China, Romania, South Africa and the U.S. For example, more than 200,000 AMD sites have been identified in the U.S., with the potential to cost up to several tens of billions of dollars for full rehabilitation [10].
In Australia, Queensland and New South Wales have approximately 60,000 and 20,000 legacy mine sites, respectively, with tens of thousands of other sites across other states in Australia (e.g. over 3,000 mine sites recorded in Tasmania); at least $10 \%$ of these legacy mine sites may contain potentially acid generating wastes. In Australia, the annual AMD liability cost was estimated in 1997 to exceed US \$120 million for operating sites and US \$650 million in inherited liability [11], a cost that would be considerably greater today. Due to both the severity and long-lasting nature of negative environmental impacts associated with AMD, it has been recognized as a very complex and costly issue for the mining industry and regulatory government sectors. Therefore, the development of long-term effective and economically sustainable strategies, implementable at mine sites, for AMD mitigation is of critical importance.

\section{AMD Generation from Pyrite Oxidation}

Pyrite is known as the major contributor to AMD generation. The (abiotic) oxidation of pyrite can be commonly represented by the following reactions (Equation 1 and 2), involving the two most common oxidants, $\mathrm{Fe}^{3+}$ and $\mathrm{O}_{2}$. The mechanisms and kinetics of pyrite oxidation have been previously extensively reviewed [1217], and readers are suggested to refer to those publications and references therein for extended reading. 


$$
\begin{aligned}
& \mathrm{FeS}_{2}+7 / 2 \mathrm{O}_{2}+\mathrm{H}_{2} \mathrm{O} \rightarrow \mathrm{Fe}^{2+}+2 \mathrm{SO}_{4}{ }^{2-}+2 \mathrm{H}^{+} \\
& \mathrm{FeS}_{2}+14 \mathrm{Fe}^{3+}+8 \mathrm{H}_{2} \mathrm{O} \rightarrow 15 \mathrm{Fe}^{2+}+2 \mathrm{SO}_{4}{ }^{2-}+16 \mathrm{H}^{+} \\
& \mathrm{Fe}^{2+}+1 / 4 \mathrm{O}_{2}+\mathrm{H}^{+} \rightarrow \mathrm{Fe}^{3+}+1 / 2 \mathrm{H}_{2} \mathrm{O}
\end{aligned}
$$

The presence of aqueous $\mathrm{Fe}^{3+}$ accelerates pyrite oxidation and AMD generation. The faster kinetics of pyrite oxidation by $\mathrm{Fe}^{3+}$ than by $\mathrm{O}_{2}$ is proposed to be due to the ease of chemical bonding of $\mathrm{Fe}^{3+}$ to the pyrite surface [15]. It is noted that one mole of pyrite oxidised by $\mathrm{Fe}^{3+}$ produces 16 moles of protons (Equation 2), an eight-fold increase as compared to that from pyrite oxidation by $\mathrm{O}_{2}$ only (Equation 1 ). $\mathrm{Fe}^{3+}$ can be formed by oxidation of $\mathrm{Fe}^{2+}$ (Equation 3), but this reaction is kinetically slow at $\mathrm{pH}<4$ [18]. As the chemical oxidation of $\mathrm{Fe}^{2+}$ to $\mathrm{Fe}^{3+}$ by $\mathrm{O}_{2}$ is negligible below $\mathrm{pH} 4$ and the regeneration of $\mathrm{Fe}^{3+}$ is the rate-limiting step during pyrite oxidation [19], the acidophilic iron-oxidising microorganisms play a vital role in the evolution of AMD at low pH [20,21]. The significance of bacteria in catalysing pyrite oxidation is well documented, with increases in pyrite oxidation rates by up to six orders of magnitude $[22,23]$. While some iron- and sulfur-oxidising microbes can accelerate pyrite oxidation and AMD generation, other microorganisms such as some beneficial oxygen-consuming and iron-reducing heterotrophic bacteria can help develop surface passivating biofilms on pyrite reducing the rate of AMD generation by limiting the availability of oxidants $\left(\mathrm{O}_{2}\right.$ and $\left.\mathrm{Fe}^{3+}\right)$ at the mineral surface and also the availability of $\mathrm{O}_{2}$ in the bulk AMD environments $[20,24]$. Therefore, the beneficial interactions between microbes and (sulfide) minerals can be used to develop microbial-based AMD remediation approaches.

\section{AMD Control}

AMD treatment options can be generally classified into two categories: source- and migration- and control [20]. Source control is defined as control measures that can prevent the formation of AMD from sulfides in the first instance, i.e. control at-source. In contrast, migration control is described as treatments that reduce the impact of the resulting AMD wastewaters on aquatic environment (i.e. treatments after AMD generation) and can be further divided into active and passive treatments - both of which can involve abiotic and biotic approaches.

\section{Source Control}

The aim of source control is to create conditions required to reduce pyrite oxidation rate by limiting $\mathrm{O}_{2}$ and water ingress to the pyrite surface. A number of control methods have been proposed including application of wet and dry covers (physical barriers), microencapsulation (surface coating), sealing of underground mines, underwater storage of mine tailings, flooding and sealing of underground mines, blending of mineral wastes, etc [20]. In this review, only the surface coating-based source control is briefly described below.
Among various at-sources approaches, mineral surface passivation is an appealing and viable approach for control of acid generation and has received increasing attention over the last two decades. Four main types of surface passivation layers developed to date are organics (abiotic) [25-27], phosphates [28,29], silicates [30-32] and biofilms [33,34]. Although the use of organics and phosphates can reduce pyrite oxidation, their application in the field in still challenging due to the high concentra rations of chemicals and harsh conditions needed to form organic coatings and possible secondary pollution from organic and eutrophication of freshwater environments by phosphates. Another potential issue with application of phosphate is that inhibition of pyrite oxidation based on this approach may only be temporary due to the formation of armoring layers on the phosphate materials used [20,35].

In our opinion, silicates- and biofilm-based surface passivation, and the recently developed pyrite passivation by $\mathrm{Al}(\mathrm{OH})_{3}$-iron (oxy) hydroxide double layers [36], are more promising, effective and potentially sustainable, as compared to other surface passivation techniques. It has been reported that pyrite oxidation rate can be reduced by $>97 \%$ over approximately 290 days at neutral $\mathrm{pH}$ with approximately $20 \mathrm{ppm}$ added $\mathrm{Si}^{4+}$ or $\mathrm{Al}^{3+}$ sources under non-stirred conditions, through the development of surface passivating layers on pyrite. Note: non-stirred (static) conditions are more commonly encounted in natural AMD environments. Under realistic AMD environments, these $\mathrm{Si}$ - or Al-containing species required for the development of surface passivating coatings can be potentially provided by the dissolution of silicates or alumino-silicates such as K-feldspar, chlorite and mica, commonly found in AMD sulfidic waste rocks and tailings. Microbial populations in AMD environments can also be manipulated to stimulate the growth of beneficial bacteria [24] (e.g. aerobic oxygen-consuming and iron-reducing microbes) and develop biofilms on pyrite surfaces [34]. It has been found previously that application of heterotrophic iron-reducing bacteria (Acidiphilium and Acidocella spp.) can reduce pyrite oxidative dissolution by about $80 \%$, even under highly acidic $(\mathrm{pH}<2$ ) and oxygen-saturated conditions, through possible formation of biofilms [37]. The presence of the biofilms also limits the availability of sulfide mineral surfaces for interactions with deleterious bacteria (e.g. iron- and sulfur-oxidising microorganisms).

\section{Migration Control}

While it is preferably to prevent or limit acid generation atsource, it is often challenging to inhibit the AMD generation from the sulfide source. Migration control then becomes the only alternative strategy for AMD treatment, where source control is not possible, and includes active and passive processes. Active treatments often involve applications of alkaline materials to neutralise acidic AMD wastewaters and precipitate metals [20], adsorption, ion exchange and membrane-based technologies [38]. Among all traditional chemical-based active treatment methods, neutralisation of AMD 
using industrial alkaline chemicals, such as hydrated lime (Ca $(\mathrm{OH})_{2}$ ) and limestone (carbonates), is more commonly used for removal of metals (as metal hydroxide precipitates) and sulfate (as gypsum precipitate) [38]. Although active treatments present high efficacies in treating AMD, they require large amounts of alkaline materials and also generate significant amounts of sludges (by-products) which require further management [1]. Passive treatments for AMD remediation are often based on natural and constructed wetland systems [39]. Some other passive treatment methods include limestone-based (e.g. anoxic and toxic limestone drains, open limestone channel), bioreactors-based (e.g. application of sulfate-reducing bacteria), permeable reactive barrier-based (application of reactive materials to induce beneficial physical, chemical and biological processes) systems and others. More details regarding active and passive treatment options can be found in previous review articles [1, 38]. Passive systems generally require relatively little maintenance as compared to active systems; however, they suffer from significant limitations as they are most suitable for treatment of AMD wastewaters with low acidity $(<800$ mg $\left.\mathrm{CaCO}_{3} \mathrm{~L}^{-1}\right)$ and flow rates $(<50 \mathrm{~L} / \mathrm{s})[40,41]$.

\section{Concluding Remarks}

AMD is acknowledged as the most serious environmental threat posed by mining to aquatic ecosystems. Treatment of AMD is complex and remediation options need to be determined largely on a case-by-case basis. For mine sites with AMD issues, the matching of acid generation rate and the acid neutralisation rate is, in principle, the only economically sustainable treatment option for long-term mine closure and site relinquishment [42]. It is preferably to preventatively limit the formation of AMD atsource where possible, through source control measures such as development of surface passivating layers on sulfide mineral surfaces. While surface passivation has been successful under laboratory conditions, scale-up and implementation at mine sites are required to test their efficacies under field conditions. The application of surface passivation and its effectiveness under realistic microbiological AMD environments also needs to be verified. Where source control is not possible, migration control is the only alternative to minimise the impact of AMD wastewaters on aquatic environments. When applying a migration control method for AMD treatment, the following aspects need to be considered: east of operation, materials availability and cost, maintenance cost system durability, the limitation of each migration control method, etc.

\section{References}

1. Zhou Y, Short MD, Li J, Fan R, Qian G (2019) Non-Carbonate Geochemical Options for Long-Term Sustainable Acid and Metalliferous Drainage Control at Source. Environ Earth sci 78(5): 15.

2. Qian G, Fan R, Short MD, Schumann RC, li J, et al. (2018) The Effects of Galvanic Interactions with Pyrite on the Generation of Acid and Metalliferous Drainage. Environ Sci Technol 52(9): 5349-5357.

3. Vaughan DJ, Craig JR (1978) Mineral Chemistry of Metal Sulfides. Cambridge university press, UK.
4. Qian G, Fan R, Short MD, Schumann RC, Li J, et al (2019) Evaluation of The Rate of Dissolution of Secondary Sulfate Minerals for Effective Acid and Metalliferous Drainage Mitigation. Chem Geol 504: 14-27.

5. Ríos CA, Williams CD, Roberts CL (2008) Removal of Heavy Metals from Acid Mine Drainage (amd) using Coal Fly Ash, Natural Clinker and Synthetic Zeolites. J Hazard Mater 156(1-3): 23-35.

6. Cheng H, Hu Y, Luo J, Xu B, Zhao J (2009) Geochemical Processes Controlling Fate and Transport of Arsenic in Acid Mine Drainage (Amd) and Natural Systems. J Hazard Mater 165(1-3): 13-26.

7. Hochella MF, Moore JM, Golla U, Putnis A (1999) A TEM Study of Samples from Acid Mine Drainage Systems: Metal-Mineral Association with Implications for Transport. Geochim Cosmochim Acta 63(19): 33953406.

8. Septoff A Hardrock mining: Acid mine drainage. Earthworks.

9. Tuffnell S (2017) Acid drainage: The global environmental crisis you've never heard of.

10. Li Y, Li W, Xiao Q, Song S, Liu Y, et al. (2018) Acid mine drainage remediation strategies: A review on migration and source controls. Miner Metal Proc 35(3): 148-158.

11. Harries JR (1997) Acid mine drainage in Australia: Its extent and potential future liability. Australia.

12. Chandra AP, Gerson AR (2010) The mechanisms of pyrite oxidation and leaching: a fundamental perspective. Surf Sci Rep 65(9): 293-315.

13. Williamson M A, Rimstidt J D (1994) The Kinetics and Electrochemical Rate-Determining Step of Aqueous Pyrite Oxidation. Geochim. Cosmochim 58(24): 5443-5454.

14. Moses CO, Nordstrom DK, Herman JS, Mills AL (1987) Aqueous pyrite oxidation by dissolved oxygen and by ferric iron. Geochim Cosmochim 51(6): 1561-1571.

15. George W Luther III (1987) Pyrite Oxidation and Reduction: Molecular Orbital Theory Considerations. Geochim Cosmochim 51(12): 31933199.

16. Mckibben MA, Barnes HL (1986) Oxidation of Pyrite in Low Temperature Acidic Solutions: Rate Laws and Surface Textures. Geochim Cosmochim 50(7): 1509-1520.

17. Rimstidt JD, Vaughan DJ (2003) Pyrite Oxidation: A State-Of-The-Art Assessment of the Reaction Mechanism. Geochim Cosmochim 67(5): 873-880.

18. Morgan B, Lahav O (2007) The Effect Of pH on the Kinetics of Spontaneous $\mathrm{Fe}(\mathrm{II})$ Oxidation by $\mathrm{O}_{2}$ in Aqueous Solution - Basic Principles and a Simple Heuristic Description. Chemosphere 68(11): 2080-2084.

19. Singer PC, Stumm W (1970) Acidic Mine Drainage: The Rate-Determining Step. Science 167(3921): 1121-1123.

20.Johnson DB, Hallberg KB (2005) Acid Mine Drainage Remediation Options: A review. Sci Total environ 338(1-2): 3-14.

21. Hallberg KB (2010) New Perspectives in Acid Mine Drainage Microbiology. Hydrometallurgy 104(3): 448-453.

22. Evangelou VP, Zhang YL (1995) A Review: Pyrite Oxidation Mechanisms and Acid Mine Drainage Prevention. Crit Rev Environ Sci Technol 25(2): 141-199.

23. Nordstrom DK, Southam G (1997) Geomicrobiology of Sulfide Mineral Oxidation. Reviews in mineralogy and geochemistry 35: 381-390.

24. Ogbughalu OT, Gerson AR, Qian G, Smart RSC, Schumann RC, et al. (2017) Heterotrophic Microbial Stimulation Through Biosolids Addition for Enhanced Acid Mine Drainage Control. Minerals 7(6): 105.

25. Diao Z, Shi T, Wang S, Huang X, Zhang T, et al (2013) silane-based coatings on the pyrite for remediation of acid mine drainage. Water res 47(13): 4391-4402. 
26. Ačai P, Sorrenti E, Gorner T, Polakovič M, Kongolo M (2009) Pyrite Passivation by Humic Acid Investigated by Inverse Liquid Chromatography. Colloids and surfaces a: Physicochemical and engineering aspects 337(1): 39-46.

27. Belzile N, Maki S, Chen YW, Goldsack D (1997) Inhibition of Pyrite Oxidation by Surface Treatment. Sci Total environ 196(2):177-186.

28. Nyavor K, Egiebor NO (1995) Control of Pyrite Oxidation by Phosphate Coating. Sci Total environ 162(2): 225-237.

29. Huang X, Evangelou VP (1993) Suppression of Pyrite Oxidation Rate by Phosphate Addition. In environmental geochemistry of sulfide oxidation, American chemical society 550: 562-573.

30. Evangelou VP (2001) Pyrite microencapsulation technologies: Principles and potential field application. Ecol Eng 17(2): 165-178.

31. Fan R, Short MD, zeng SJ, Qian g, li J (2017) The formation of silicatestabilized passivating layers on pyrite for reduced acid rock drainage. Environ Sci Technol 51(19): 11317-11325.

32. Kargbo DM, Chatterjee S (2005) Stability of silicate coatings on pyrite surfaces in a low ph environment. J Environ Eng 131(9): 1340-1349.

33. Kalin M, wheeler WN, Bellenberg S (2018) Acid rock drainage or not oxidative vs Reductive biofilms a microbial question. Minerals 8(5): 199.

34. Johnson DB (2014) Recent developments in microbiological approaches for securing mine wastes and for recovering metals from mine waters.
Minerals 4(2): 279-292

35. Evangelou VP (1998) Pyrite chemistry: The key for abatement of acid mine drainage. In acidic mining lakes: Acid mine drainage, limnology and reclamation. Springer berlin Heidelberg, Germany, pp. 197-222.

36. Zhou Y, Fan R, Short MD, Li J, Schumann RC (2018) Formation of aluminum hydroxide-doped surface passivating layers on pyrite for acid rock drainage control. Environ Sci Technol 52(20): 11786-11795.

37. Johnson DB, Yajie l, Okibe N (2008) "Bioshrouding”-a novel approach for securing reactive mineral tailings. Biotechnol Lett 30 (3): 445-449.

38. Kefeni KK, Msagati TAM, mamba BB (2017) Acid mine drainage: Prevention, treatment options, and resource recovery: A review. J clean Prod 151: 475-493.

39. Akcil A, koldas S (2006) Acid mine drainage (amd): causes, treatment and case studies. J clean Prod 14(12-13): 1139-1145.

40. Berghorn GH, Hunzeker, GR (2001) passive treatment alternatives for remediating abandoned-mine drainage. Remediation 11(3): 111-127.

41. Taylor J, Pape S, Murphy N (2005) In a summary of passive and active treatment technologies for acid and metalliferous drainage. Australia.

42. Gerson AR, Li J, Smart RSC, Saint CP, Short MD, et al. (2014) Responsible management of acid mine wastes: Geochemical and microbiological resources. In Responsible Mining: Sustainable Practices in the Mining Industry, pp. 519-542.

\section{(C) () \\ This work is licensed under Creative Commons Attribution 4.0 License}

To Submit Your Article Click Here:

Submit Article

DOI: $10.32474 / J O M M E .2019 .01 .000101$

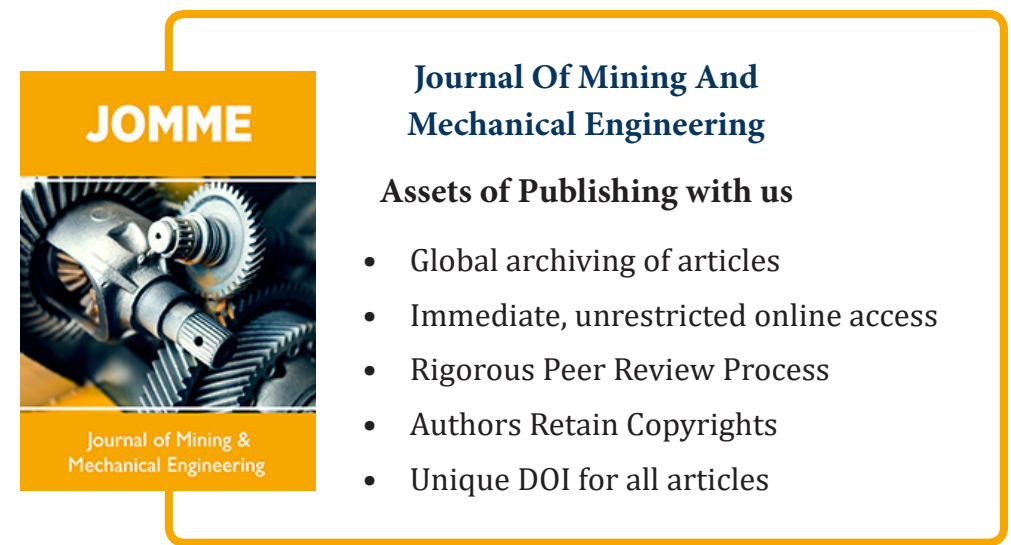

